\title{
Paradoxes Regarding Urban Development: The Case of Dom Expedito, Sobral-Ce
}

\author{
Paula Mirelle Chaves Costa ${ }^{1}$ \\ Francisco Clébio Rodrigues Lopes ${ }^{2}$
}

\begin{abstract}
Sobral has gone through structural changes in his territory and has reaffirmed his influence in the urban zone of Ceará. In this context, the Dom Expedito neighborhood stands out because its urbanization process took place the arrival of tertiary activities with precarious spaces in its interior. This manuscript analyzes the fragmentation of the area into territories and the relationship between the Terra Nova allotment and the Gaviões community. The urban space development includes characteristics such as segregation, which is the process that the population demands and enjoys the city in different ways. The visits and interviews carried out with long-term residents revealed their displeasure regarding the modernization process. When considering their precarious condition and comparing the transformation between this community and other areas of the city, it is clear that it is a forgotten neighborhood.
\end{abstract}

Keywords: Urban zone development. Gaviões community. Segregation.

\section{Introduction}

The current urbanization relates to the valorization of territory for capitalist purposes.The paradox lies in the simultaneous production of investment centers and surrounding areas. In large part, this process turns to those who can pay, turning the city into exchange value.

The research studied the Dom Expedito neighborhood in Sobral (CE), initially recognized as The Other Side of the River. It has experienced changes in the last ten years with the installation of tertiary activities, promoted by tax incentives, and gained centrality in the city.

We sought to analyze the fragmentation of the neighborhood into territories of use and the relationship between Terra Novaallotment and the Gaviões community. Thus, we conducted a literature review in Ferreira (2013), Fontenelle (2015), Alvaraz (2018), Carlos (2018), Spósito (2018), and Freitas (2019). Also, as methodological procedures, we collected statistical data at Casa do Contribuinte de Sobral, CRAS Mimi Marinho, and visited the Gaviões community to have informal conversations and indirect interviews.

Based on these data, it occurred a thorough analysis of the changes that occurred not only in Dom Expedito but also in the wholecity, presented by the media as a case of success. Unquestionably, Sobral plays a significant role in the region, but a large part of its dwellers remained on the edge of its economic growth. Thus, the fieldwork in the Gaviões community revealed an area lacking in public policies, which highlighted elements of segregation.

This paper starts in the introduction by exposing some points of the research. Then, it deals with the urbanization that took place in Sobral, going throughmoments that assisted in its consolidation and its relevance in the state of Ceará. After that, it approaches Dom Expedito neighborhood by making a brief analysis of its occupation and the urban transformation. The fourth topic highlights the paradoxes in the Gaviões community. Finally, it discusses the segregation resulting from capitalist urbanization.

\section{From Caiçara Farm to Sobral City}

Recently, a state law instituted the metropolitan region of Sobral (figure 1) due to the large-scale integration with colleges and universities, hospitals, business areas, and industrial activities among eighteen municipalities in the northwestern Ceará. This fact has reinforced the centrality of Sobral inside the state. However, it is necessary to seek the historicity of this phenomenon.

\footnotetext{
${ }^{1}$ Geographystudentat Universidade Estadual Vale do Acaraú (Acaraú Valley StateUniversity, UVA), Sobral, Ceará.Assistedby PIBIC/CNPq. mirellecosta.12@gmail.com

${ }^{2}$ Prof. Dr. at UVA, Sobral, Ceará. clebiolopes@ yahoo.com.br
} 
Figure 1-Sobral and itsmetropolitan region, 2016

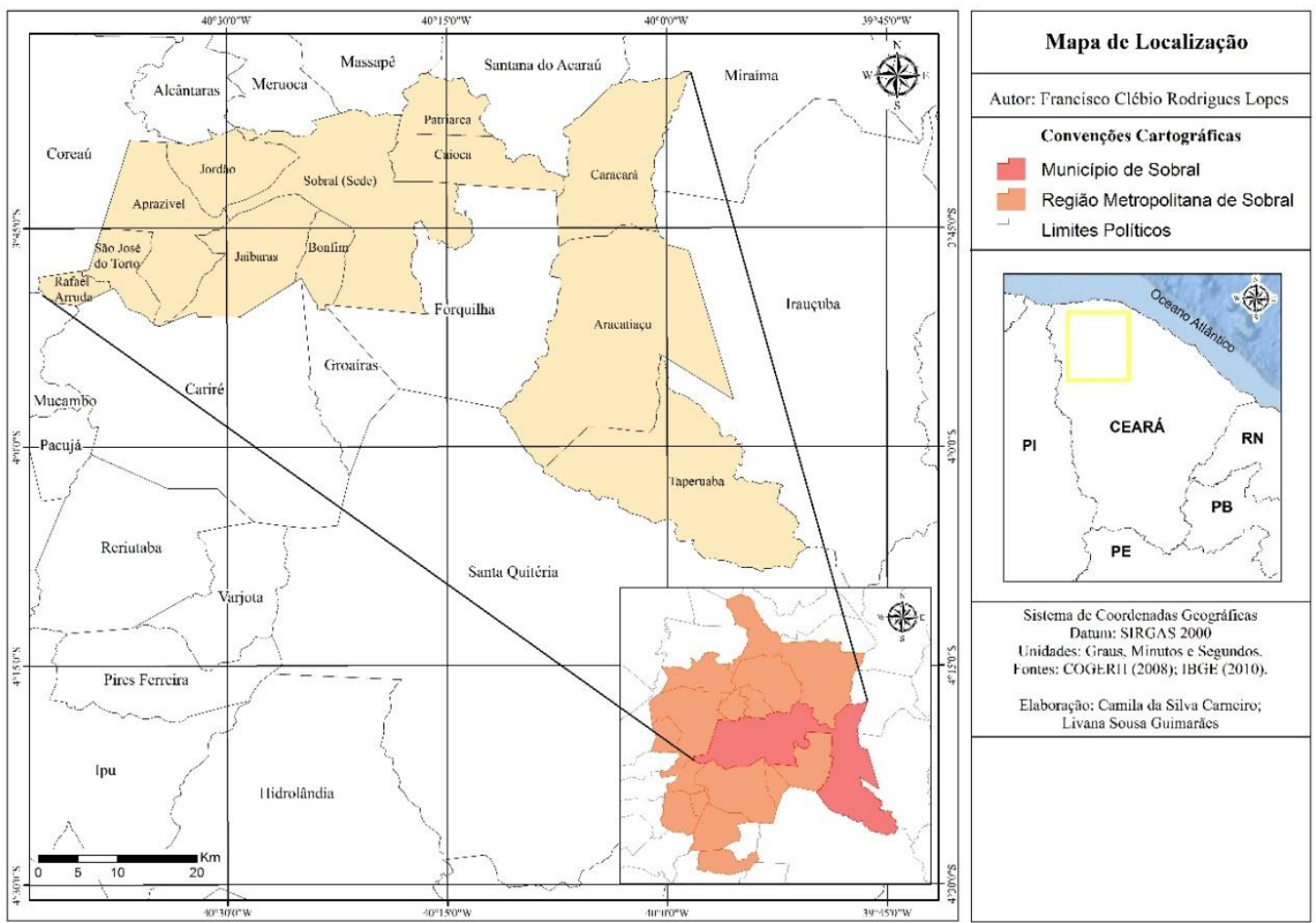

Source-COGERH, 2008; IBGE, 2010.

From the idea that the city is a historical and social product, so it changes according to society (CARLOS, 2018).This way, the socio-economic relations in the colonial period allowed the establishment of a small warehouse on the banks of the Acaraú River in the 18th century. Caiçara farm- the previous name for Sobral -sought to centralize the production of livestock in the region and send it to Pernambuco and Bahia through the port in Acaraú (FERREIRA, 2013).

After the movement of money had intensified, the urban zone expanded and required good-quality urban planning bybuilding streets, squares, and buildings. The arrival of cotton and the integration of Ceará into the world market demanded faster transportation, hence the implementation of the railroad. At the beginning of this process, cotton processing and oil production factories established themselves in the city.

The modernization of the state began in the 20th century under the administration of Governor VirgílioTávora (1979-1982).The encouragement for industrial activities sought the consolidation of the manufacturing center in Ceará. However, the effects of this policy were noticeable only after the implantation of a footwear factory called GRENDENE in 1993, giving relevance to the secondary sector.

Industrialization brings about structural changes in the territory because it drives urbanization and transforms infrastructure (SPÓSITO, 2018). Thus, the city of Sobral has broken its old boundaries, and the urban zone has advanced beyond the train track and the Acaraú River. Until mid-nineties, it was possible to say that downtown where the high society used to live - was the area surrounded bythe train track, and the periphery was the area outside this perimeter.

The last decade of the 20th century is relevant in the urban development of Sobral because the insertion of the city in a scenario of global urban competition has demanded actions to attract new investments. Cid Ferreira Gomes's two managements were responsible for this role. The first, called Sobral on the right path, lasted from 1997 to 2000 and implemented structural changes in the management. Besides that, it strengthened the cultural policy through the overthrow of the historic center by IPHAN and renewed the urban space by creating the Plano Diretor de Desenvolvimento Urbano (Urban Development Master Plan, PDDU). In the second (2001-2004), which appointed Sobral to be ready for the future, there were great works such as the urbanization of the Acaraú River left bank, renewal of the Othon de Alencar Bridge, implementation of a big park, construction of the Arco Boulevard and expansion of roads and avenues.

According to Ferreira (2013), the changes reflect a political reorganization of space, being for the municipal public administration a requalification and modernization of the city. 
Alvarez (2018) states that revitalization and modernization reveal that the process guides the selectivity of investments and subjects to be attracted to these areas.

The changes between 1997 and 2004 in the urban zone of Sobral did not mean development, as economic growth brought new investments. However, it caused the expansion of the peripheral area. With this, Dom Expedito stands out because its urbanization process happened with the arrival of new tertiary activities, keeping poverty inside the neighborhood. This research analyzes the fragmentation of this neighborhood into territories of use and the connection between Terra Nova allotment and the Gaviões community.

The territories of use are present in everyday life because, according to Seabra (2004), capitalist urbanization makes it emerges as an analysis to understand the changes in the use of time. The paradoxes generated by capitalist urbanization can be made clear from the forms of use of time in places and daily life as a sphere of analysis of the contradictions (exclusion and inequalities) for the construction of the capitalist urban space. On one side, the private companies on Monsenhor Aloísio Pinto avenue, and on the other, Gaviões community.

\section{The Other Side of the River}

Dom Expedito, according to Fontenelle Filho (2015), initially known as The Other Side of the River, is on the right bank of the Acaraú River. The author highlights the most relevant characters in the history of this neighborhood: laundresses, canoeists, fishermen, and bathers.

The occupation had begun between the 1930s and 1940s but became official in 1962, receiving the name of Monte Castelo. Its current denomination honors a bishop murdered in 1957. The expansion took place under the management of Paulo de Almeida Sanford (1955-1958) after the allotment of Dom Evangelina Sabóia (FONTENELLE FILHO, 2015) had got authorization.

According to a study developed by the Social Assistance Reference Center - CRAS Mimi Marinho, called Territorialization of Dom Expedito Neighborhood (2019), the business growth attracted needy people and also those who were fleeing the droughts. At first, the zone served as a dormitory, since there was no electricity, running water, churches, and schools. The population that settled there had the only option to serve the high society who lived in other areas. Until 2000, the neighborhood had a precarious infrastructure and was home to a community with strong rural characteristics (AGUIAR JÚNIOR, 2005).

The neighborhood has suffered modifications in its territory over the past few years due to the construction of Prefeito José Euclides Bridge and the opening of MonsenhorAloísio Pinto Avenue. The goal was to connect the two river banks and establish communication between Dom Expedito and SinháSabóia. Instead, the avenue became a commercial passageway in the management of LeônidasCristino (FONTENELLE FILHO, 2013). The city hall encouraged the arrival of tertiary activities through the Desenvolvimento Econômico de Sobral (Sobral Economic Development Program, PRODECON), created in 2001 by Municipal Law number 313. Through tax incentives, loans, implementation of infrastructure, and donation of land in Terra Nova allotment, the project attracted enterprises to Dom Expedito.

The changes have made turned the neighborhood into a new centrality. Spósito (2018) states that these zones, which emerge in the city, are a commercial and service surface planned intentionally by a small group of stakeholders. The services offered, such as the mall, exerts a new flow to the area, increasing the city's network of influence.

The document Territorialização do Bairro Dom Expedito (2019) highlights some situations of vulnerability and risk faced by the residents, among them are drug traffic, conflicts of territorial limitations, and sexual exploitation. The drug traffic, according to this document, is in Campo Grande street, Espanha street, Lucimar street, Itália street, Caubi Vasconcelos street, and Antônio Rodrigues Magalhães intersection. Regarding territorial limitation, part of the population from Dom Expedito does not have free movement through Parque Santo Antônio and Tamarindo because of the imposition of criminal gangs. At last, sexual exploitation is in MonsenhorAloísio Pinto Avenue.

In this article, Corrêa (1993) goes over the elements responsible for producing the urban zone, such as municipal bodies that have been responsible for modifications, development, and segregation. Therefore, it is worth mentioning the Gaviões community.

\section{The Gaviões Community}

The Gaviões community, in Dom Expedito, surrounds notorious buildings such as Sobral shopping mall and Cameron tower. The closeness to these establishments clearly shows the inequalities in the construction of the urban area. On one side, there is the Gaviões community, a proletarian population that lives in precarious conditions, and on the other, there is a modern development (Figure 1). 
Figure 1: The difference between Cameron tower andthe Gaviões community.

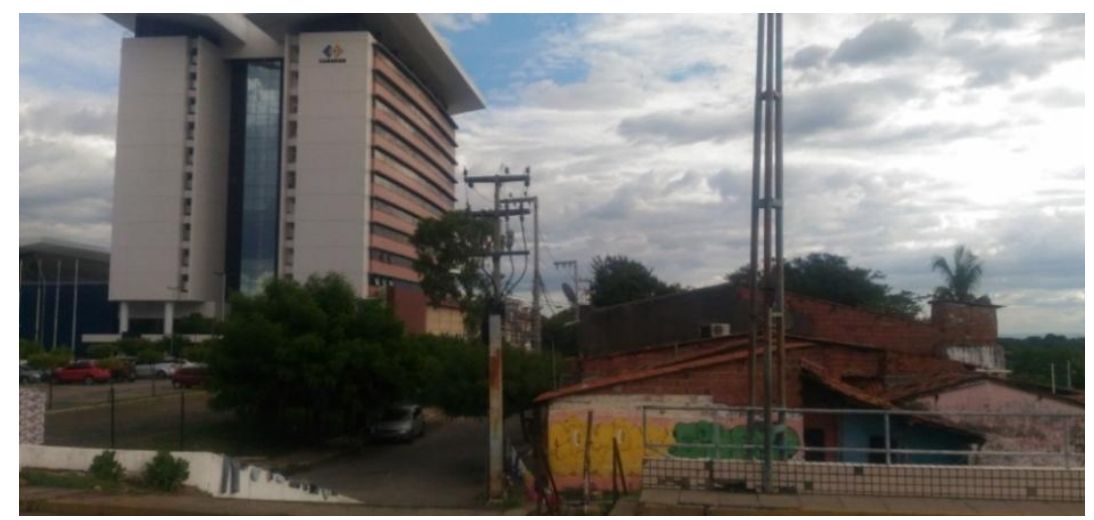

Source: Costa (2019)

When entering Dom Expedito, it is possible to identify the difference in the landscape. From far, one can see clothes hanging near the parking lot of the mall and the tower, side by side with a sign that says, "Attention! Please, do not hang clothes on the fence." (Figures 2 and 3).

Figures 2 and 3: Sign placed in the fencesof Sobral shopping mallandCameron tower.

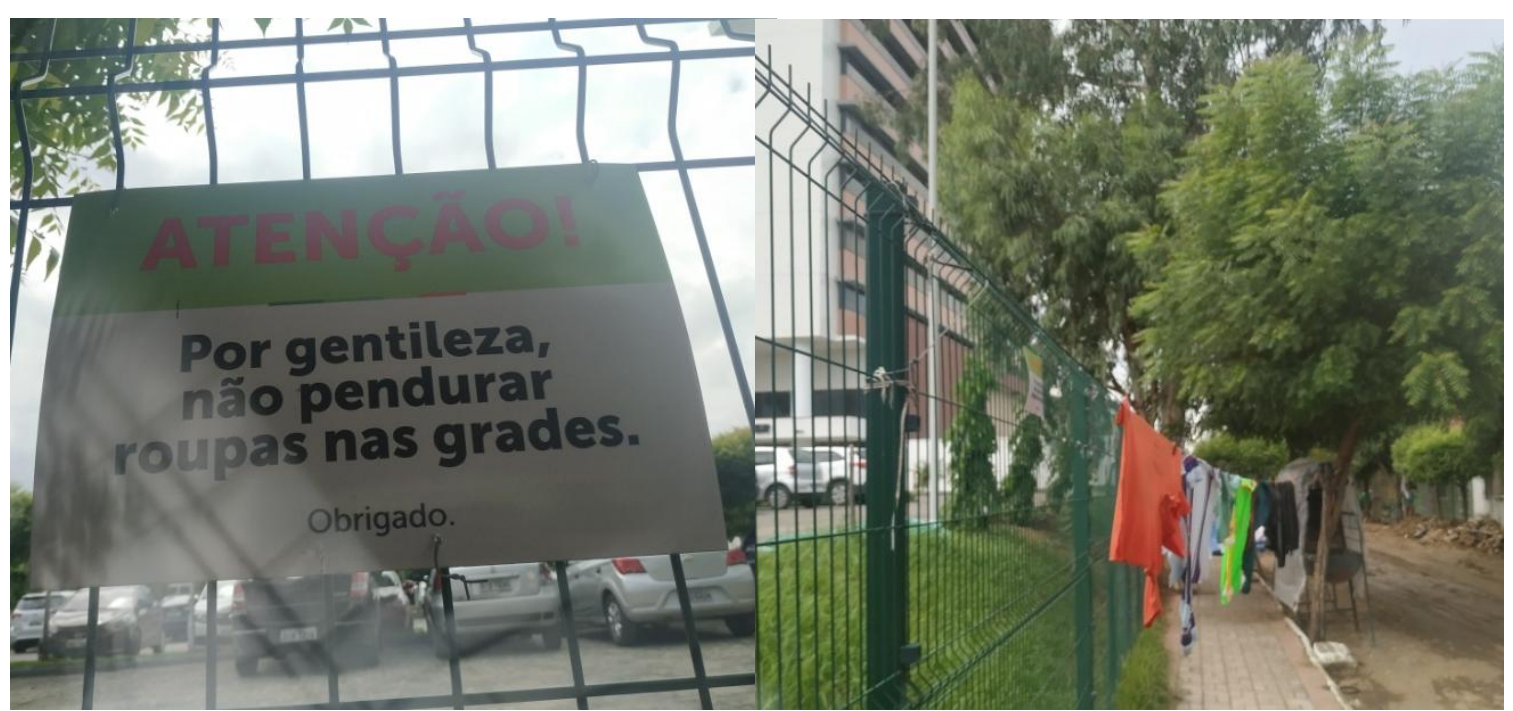

Source: Costa (2020).

According to the 2008 participative master plan of Sobral, the Gaviões community is a Zona Especial de Interesse Social (Special Zone of Social Interest, ZEIS). ZEIS should receive special treatment in matters of housing and implementation of equipment that allows the permanence of the local population. However, it is clear that the action of the municipal bodies has little intervention in the area and that the community goes through some conflicts due to the development conditions.

The PDDU is under review, so community readings of the plan took place in early 2020 all around the city. A workshop with residents from Dom Expedito, Várzea Grande, and Antônio Carlos Belchior took place on January 22 to discuss the problems and potentialities of the area. The participants gave suggestions for different topics, such as housing, work, infrastructure, leisure, environment, and mobility. The population from Dom Expedito emphasized the need for recreation areas and proposed the construction of a square for children. Besides that, there were suggestions for sewage networks absent in many homes, drainage of streets, and revitalization of the Acaraú River.

Some visits made to the community sought to understand conflicts and contradictions, as spatial production takes place in daily life and appears as a form of occupation and use of a specific place and time (CARLOS, 2018). There were also indirect interviews with the oldest residents in that neighborhood and with one of its representatives.

Through conversations with the residents, they stressed the positive and negative points of implementing the trade there. 
The population highlighted as positive the increase in real estate prices because the construction of Sobral shopping mall improved lighting and movement in its surroundings. It is possible to notice this valorization ${ }^{3}$ by observing the value of the square meter on MonsenhorAloísio Pinto avenue (Table 1).

Table 1: Square meter price on Espanha street and Dom Expedito street in 2010 and 2019.

\begin{tabular}{|l|l|l|l|}
\hline \multirow{2}{*}{ Section } & \multicolumn{2}{|l|}{ Year/Price (R\$) } & \multirow{2}{*}{ Increase (\%) } \\
\cline { 2 - 3 } & 2010 & 2019 & \\
\hline $\begin{array}{l}\text { From Dom Expedito street to } \\
\text { the intersection with Hélio } \\
\text { Arruda Coelho street }\end{array}$ & 2,40 & 350,00 & 14483,33 \\
\hline Remaining area & 2,40 & 550,00 & 22816,67 \\
\hline Espanha street & 2,40 & 350,00 & 14483,33 \\
\hline
\end{tabular}

Source: Sobral city hall (2019)

Made by Costa (2020)

In 2010, the square meter price from Dom Expedito street to the intersection with Hélio Arruda Coelho street, and Espanha street was $\mathrm{R} \$ 2.40$. In 2019, this value was $\mathrm{R} \$ 350.00$, which is an increase of $14,483.33 \%$. The remaining area used to cost, in 2010, $\mathrm{R} \$ 2.40$, and in 2019 it was $\mathrm{R} \$ 550.00$, an increase of $22,816.67 \%$. Thus, there was an exorbitant increase in the soil in this area due to the tertiary developments. The values presented correspond to the market value of the square meter, which refers to the price stipulated by the public authorities, and refers to an estimated sales value.

In the various visits to the community, everyone claimed the lack of sanitation. Salvador et al. (2010), in their study on the sanitary conditions of Dom Expedito, found that there are still some areas with open sewer and that the river is its destination. This picture has not changed even after a decade because it is the guideline for debates of the residents. The construction of a sewage system is currently going on because of many requests and fights (Figures 4 and 5).

Figures 04 and 05: Implementation of a sewage network in Dom Expedito street.

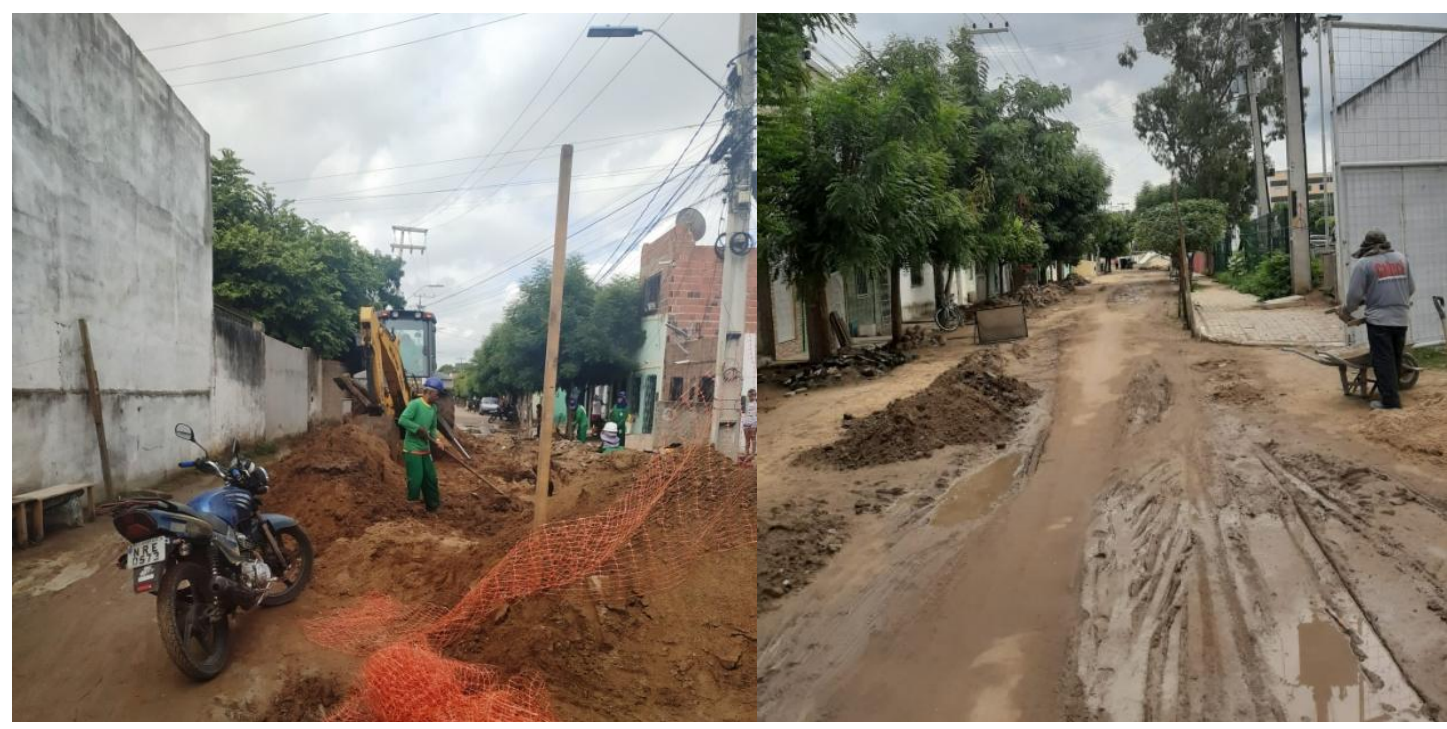

Source: Costa (2020)

In an interview with a community representative ${ }^{4}$, we asked if they had been fighting for a sewerage network for a long time, to which he said:

Last year I made a petition and took pictures of how the backyards were, how water was disposed of since many people here don't have a cesspool they throw it outdoors, it's an open sewer.

\footnotetext{
${ }^{3}$ When analyzing this valorization, one must bear in mind that some entrepreneurs have long been watching this community, pressuring the population to sell their properties. For they seek to expand their business, but because the area is a ZEIS, it is necessary that there is an emptying to occur such expansion.

${ }^{4}$ They are responsible for taking the demands required by the population, delivering them to the city hall in order to have the problem solved. Besides, they call attention of the people to some issues.
} 
Then I took photos, printed them off, signed the petition, which more than two hundred residents signed it, and then took it to the city hall so the mayor could see it. He gave his word during his campaign and fulfilled it, so this year the sanitation work is going to start (Interviewee A on February 18, 2020).

Another relevant point was the lack of spaces forleisurebecause they expressed that there is no recreational area for children. The neighborhood has only two squares, and these are in a precarious situation. The residents attest that the only leisure area that existed within the community was the soccer field (figure 6), where today is the parking lot of the mall and the Cameron tower:

The mall was a soccer field where a group of men dressed like women used to play soccer. You had to see how funny it was. It was leisure taken from us because of the construction of the mall. We lost the only points we had, and now in Dom Expedito, there is no more soccer field, that is, no leisure (Interviewee C on February 18, 2020).

Figure 6: Previous soccer field of the Gaviões team.

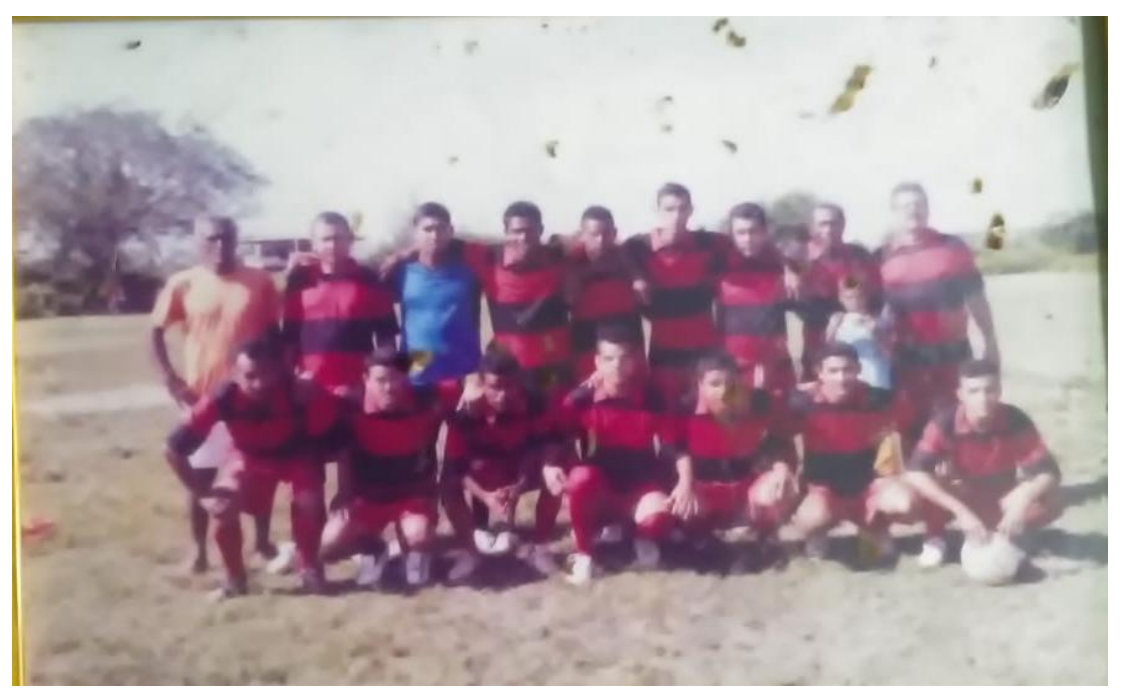

Source: Given by a resident from Dom Expedito street (2019)

Another stressed point is on the river.Since the construction of this neighborhood, the population has always had feelings for it, but from the works on the left bank, they ended up losing another leisure area. They report that the river used to be like a beach, the meeting point on weekends.There, they used to make tents and sell food and drinks to get an extra income, but because of the pollution and the water, this activity has become extinct. From the interviews, we asked what left the river like this and how it was before, and one resident said:

With the construction of the bridge and the floodgates, the river became it is today. The sewers from Santa Casa neighborhood and from the mall flow into the river. I believe this is bad-quality water. People were talking about its revitalization, that the problem is bushes, but it is much more than that. Only those who lived in this region know what the river used to be. The river was good, and its sands served soccer fields. During the carnival, there were many people, music bands hired by the city hall for the community. Many people enjoyed the event to sell things to raise money. The river was very lively and clean, and the weekend was on the Acaraú River. When I remember the river like that, I miss it because it used to be where people gathered on weekends (Interviewee E on February 18, 2020).

The laundresses were classic characters present in the Other Side of the River, but they are also disappearingbecause of the abovementioned constructions. They claim that washing clothes thereis now unfeasible, but some people still doit when they have no water at home.

Regarding the Gaviões community, it was possiblethrough conversations to reconstruct its history. The name Gaviões, as older residents report, is because the first family that inhabited this place, whoselast name wasGavião.So, the entire Dom ExpeditoandEspanha streetsreceive this name. These inhabitants began by occupying the land and took possession of it, today some of the residents resort to usucapion. According to some of the older inhabitants, these seized lands belonging to Mr. Pedro Guimarães.

Through research carried out in aregistry office in 2018, it was possible to make a genealogy of the lands where the mall and the Terra Nova allotment are. One of thembelongedto Pedro Guimarães,but Sobral expropriated it (Figure 7). 
Figure 7: History of owning of Terra Nova allotment.

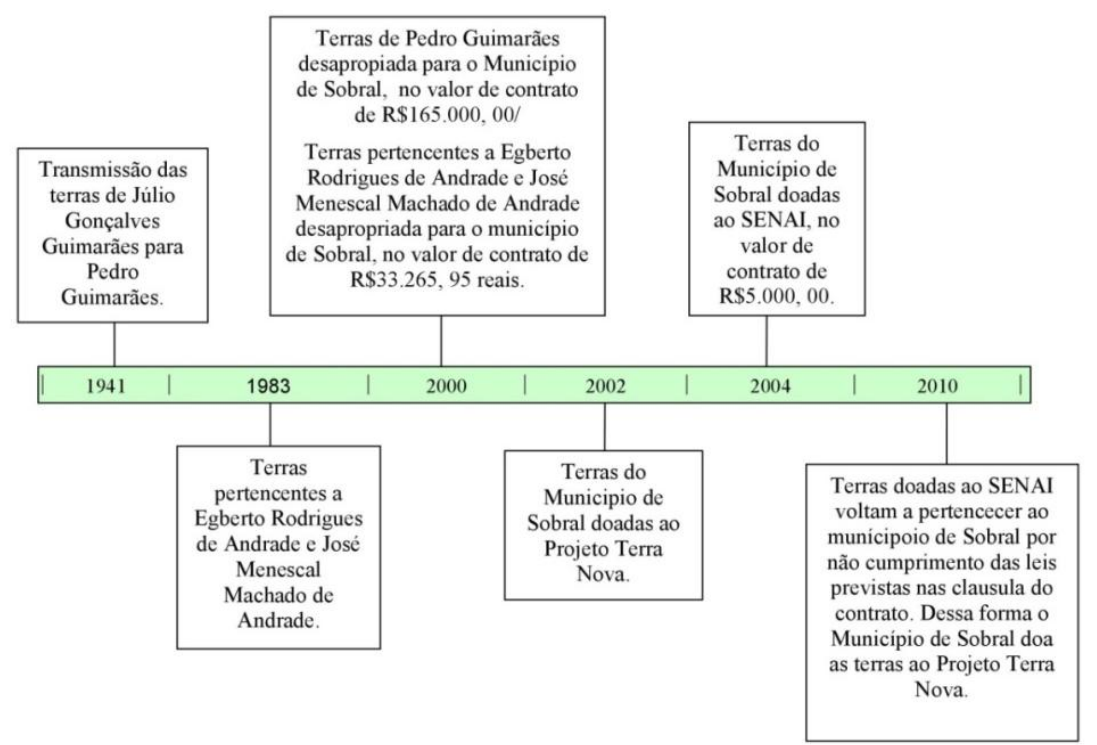

Source: $1^{\circ}$ Ofício de Sobral Registry Office (2018). Made by Costa (2018).

Another significant fact is pottery. The oldest residents from that neighborhood exposed that they worked makingbricks, and it was one of the activities used by the population to make money. While the men made bricks, the women made handicraft products, such as pots and crockery, to sell in the market. The population no longer carried out this activity according to their will after the installation of some ventures, such as Luciano Feijão College. Another hypothesis is that external factors, such as the entrance of the galvanized tile, may have led the potteryto fail.

The occupation and use of the territory in the Gaviões community have changed over time. The living area used to be a place of celebration and work, being used in different ways than today because, through the dilapidation and structural changes that occurred in the Dom Expedito neighborhood, people lost these zones. According to Seabra (2004), the space created from capitalism develops territories of use, which are spaces of consummate segregation. Despite many problems, the population has a close relationship with that place, and they express that they do not intend to live in another neighborhood. They say this is the best place to live in Sobral sincethe streets are quiet, there is no violence, and the relationship among the people is friendly.

\section{Segregation as the Product of the Capitalist Urbanization}

The production of urban space and its development involves a series of characteristics such as segregation. It is quite the opposite of a meeting, much more than differentiation and separation, the process whose population demands and enjoys the right to the city ${ }^{5}$ differently.

For Spósito (2018), segregation refers to the relationship between a part and the whole city and denotes a great theoretical value to understand the current urban reality. Thus, we aim to verify possible elements of segregation in this research.

Vasconcelos (2018), in his studies on segregation, provides on the historical creation of the term. It was born the Guettos of Venice with the seclusion of Jews in an islet with walls and doors. Spósito (2018) says that discussions about it started because of the Chicago School, with contributions of Park, Burges, and McKenzie. Years later, the French School held further debates.

The urbanization of Sobral has forgotten some areas like the Gaviões community. The working class inhabited areas far from downtown, known as a part from the train track. Through this fact, there have been traces and elements of segregation since the historical construction of Sobral. As explained by Freitas (2019), some laws made it difficult to establish the least favored class in downtown because they did not have the resources to build houses with specific characteristics, being forced to live in peripheral areas. 
DomExpedito has elements of segregation identified through visits, conversations, and interviews carried out in the Gaviões community. Regarding the residents, it is evident that they feel forgotten when comparing themselves to the rest of the city, and even within the neighborhood. They put that very close areas receive a differentiated treatment:

The street here has fallen to oblivion. From the bridge on everything is organized, here is not. In an election year, candidates come here, but they do nothing. There should be a square, but there is darkness instead (Interviewee $\mathrm{F}$ on February 18, 2020).

The forgetfulness, mentioned by the residents of the community, means less action by public agenciesbecause of the problems and demands. According to Freitas (2019), in segregated areas, there is less action by the State - the municipal sphere in this case. It appears when they say that the other street is tidy and theirs is not the same.

It causes one admiration when seeing how long this population has spent without basic sanitation and with poor sanitary conditions. Besides that, the incorrect disposition of water and thrash, which happens most of the time in their backyard, makes them live with odor and the damage caused.

Concerning a recreational area for young people and children, the one that existed close to the community does not longer exist since its removal aimed to favor the facilities of companies. Nowadays, children play indoors, which is not big enough, or on the streets, which are dangerous because of the traffic.

In the various losses of public spaces over the years because of the installation of enterprises, the community finds itself amid the new uses of the area, and there are no more common spaces left.

\section{Final Considerations}

Capitalist production does not create spaces for the citizen, but for the consumer instead. The changes that take place within the city tend to meet the financial needs for its reproduction. Thus, the city, through its development process, loses its value of use and gains exchange value.

Sobral has recently undergone structural changes in its territory, reaffirming its influence in surrounding cities and the role in the urban network of Ceará. According to the media, it is a case of success. However, one must understand that this production is not for everyone, but for those who are searching for transformation.

The visits, conversations, and interviews carried out in the study area attest to this fact and through speech the dissatisfaction of those who do not enjoy this modernization of the city, who live precariously, oblivious to the transformations that have occurred in its surroundings, proving that people forgot it in comparison with the urban whole.

\section{Acknowledgement}

Conselho Nacional de Desenvolvimento Científico e Tecnológico (NationalCouncil for ScientificandTechnologicalDevelopment, CNPq)

\section{References}

AGUIAR JR. Paulo Rocha. A cidade e o rio: produção do espaço urbano em Sobral - Ceará. 2005.180f. Dissertação (Mestradoem Desenvolvimento e Meio Ambiente - PRODEMA) - Universidade Federal do Ceará, Fortaleza, 2005.

ALVAREZ, P. I. A segregação como conteúdo da produção do espaço urbano. In: VASCONCELOS, P. A et al. (Orgs.). A cidade contemporânea: segregação espacial. 1 ed., $2^{\mathrm{a}}$ reimpressão.São Paulo: Contexto, 2018. p. 111-126.

CARLOS, A. F. A. O uso do solo urbano. In: A cidade. 9 ed. São Paulo: Contexto, 2018. p. 45-49. .Repensando a noção de cidade. In:___ _. A cidade. 9 ed. São Paulo: Contexto, 2018. p. 67-81. . A prática espacial urbana como segregação e o "direito à cidade" como horizonte utópico. In: VASCONCELOS, P. A et al. (Orgs.). A cidade contemporânea: segregação espacial. 1 ed., 2 $2^{\mathrm{a}}$ reimpressão.São Paulo: Contexto, 2018. p.95-110.

CENTRO DE REFERÊNCIA ASSISTÊNCIA SOCIAL (CRAS) - Relatório de territorialização do bairro Dom Expedito. Sobral, 2019.

CORREAA, R. L. Quem produz o espaço urbano? In: O Espaço Urbano. 2 ed. São Paulo: Ática, 1993. p.1135.

FERREIRA, D. L. A (re)invenção de uma cidade: Cid Marketing e a requalificação urbana em Sobral-CE. 2013. 316f. Tese (Doutorado do Programa de Pós-Graduação em Ciências Sociais). Universidade Estadual de Campinas - Unicamp. Campinas-SP, 2013.

FONTENELLE FILHO, J. As Transformações Socioespaciais no Bairro Dom Expedito em Sobral-CE.2015. 158f.Dissertação (Mestrado em Geografia). Universidade Estadual Vale do Acaraú. Sobral-CE, 2015. 
FREITAS, A. J. L. Sobre viver em Sobral-Ce: da segregação à estigmatização socioespacial nos territórios da violência e do medo. 2019. 258f. Dissertação (Mestrado em Geografia). Universidade Estadual Vale do Acaraú. Sobral-CE, 2019.

PREFEITURA MUNICIPAL DE SOBRAL. Lei complementar $n^{\circ} 028$ de 15 de dezembro de 2008. Dispõe sobre Plano Diretor Participativo do Município de Sobral. Secretaria de Urbanismo e Meio Ambiente. Sobral, 2008. Disponível em: 〈http://seuma.sobral.ce.gov.br/images/leis/plano-diretor-2008-compressed.pdf>. Acesso em: 10 jan. 2020.

SALVADOR, J. M. et al. Análise das condições sanitárias do bairro Dom Expedito em Sobral, Ceará, pelo grupo tutorial do programa de educação pelo trabalho para saúde (PET-SAÚDE). Revista SANARE, Sobral, v. 9, n. 1, p.29-32, jan./jun. 2010.

SEABRA, O. C.de.L. Territórios do uso: cotidiano emodo devida. Cidades, Presidente Prudente -SP, v.1, n. 2, p. 181-206, 2004

SPOSITO, M.E.B. Industrialização e urbanização. In: Capitalismo e urbanização. 16 ed. São Paulo: Contexto, 2018. p. 42-60.

. Segregação socioespacial e centralidade urbana. In: VASCONCELOS, P. A et al. (Orgs.). A cidade contemporânea: segregação espacial. 1 ed., $2^{\mathrm{a}}$ re. São Paulo: Contexto, 2018. p. 61-93.

VASCONCELOS, P. A. Contribuição para o debate sobre o processo e formas socioespaciais nas cidades. In: VASCONCELOS, P. A et al. (Orgs.). A cidade contemporânea: segregação espacial. 1 ed., $2^{\mathrm{a}}$ re.São Paulo: Contexto, 2018. p. 17- 38. 